\title{
The Crime of Conspiracy Thrives in Decisions of the United States Supreme Court*
}

\author{
Paul Marcus**
}

\section{INTRODUCTION}

For most of the past century, the crime of conspiracy has generated a good deal of controversy before the Supreme Court. Whether with issues concerning broadening a hearsay exception based on a purported conspiracy to conceal as part of an initial agreement ${ }^{1}$ or with the limits of proof as to individual membership in a conspiracy, ${ }^{2}$ the Justices consistently looked with care at the reach of the crime.

*(C) Paul Marcus, 2015. Portions of this paper were initially presented in a talk at the University of Kansas in September, 2014.

**Haynes Professor of Law, College of William and Mary.

1. Krulewitch v. United States, 336 U.S. 440, 443-44 (1949), made the point clearly that such government theories would be closely scrutinized:

Although the Government recognizes that the chief objective of the conspiracytransportation for prostitution purposes - had ended in success or failure before the reported conversation took place, it nevertheless argues for admissibility of the hearsay declaration at one in furtherance of a continuing subsidiary objective of the conspiracy. Its argument runs this way. Conspirators about to commit crimes always expressly or implicitly agree to collaborate with each other to conceal facts in order to prevent detection, conviction and punishment. Thus the argument is that even after the central criminal objectives of a conspiracy have succeeded or failed, an implicit subsidiary phase of the conspiracy always survives, the phase which has concealment as its sole objective....

We cannot accept the Government's contention. There [is a] ... prerequisite to admissibility, that hearsay statements by some conspirators to be admissible against others must be made in furtherance of the conspiracy charged, [which] has been scrupulously observed by federal courts. The Government now asks us to expand this narrow exception to the hearsay rule and hold admissible a declaration, not made in furtherance of the alleged criminal transportation conspiracy charged, but made in furtherance of an alleged implied but uncharged conspiracy aimed at preventing detection and punishment.... The rule contended for by the Government could have far-reaching results. For under this rule plausible arguments could generally be made in conspiracy cases that most out-of-court statements offered in evidence tended to shield coconspirators. We are not persuaded to adopt the Government's implicit conspiracy theory which in all criminal conspiracy cases would create automatically a further breach of the general rule against the admission of hearsay evidence.

2. Contrast, for instance, the holdings in Direct Sales Co. v. United States, 319 U.S. 703, 714 (1943), and United States v. Falcone, 311 U.S. 205, 210-11 (1940). The former allowed for convictions without any direct evidence of conspiratorial involvement, while the latter did not. 
In recent years, however, that careful look has vanished as the Court has time and again rendered decisions strongly in favor of government conspiracy prosecutions using as a key basis the dangers to society of the offense. With little review, one can see that this state of affairs was not always so.

For many years, Justices of the United States Supreme Court expressed serious reservations about the reach of the conspiracy charge and the problems created at trial by the charge. ${ }^{3}$ Perhaps no member of the Court more forcefully made this point than Justice Jackson in this oftquoted concurring opinion of more than one-half century ago:

There is, of course, strong temptation to relax rigid standards when it seems the only way to sustain convictions of evildoers. But statutes authorize prosecution for substantive crimes for most evildoing without the dangers to the liberty of the individual and the integrity of the judicial process that are inherent in conspiracy charges. We should

3. Two of the more prominent illustrations are Grunewald v. United States, 353 U.S. 391, 402 (1957) (application of the statute of limitations for "concealed" conspiracy actions), and Yates $v$. United States, 354 U.S. 298, 311 (1957), overruled by Burks v. United States, 437 U.S. 1, 18 (1978) (restricting the use of the Smith Act, crime of sedition). In Grunewald, the Court wrote:

[A]llowing such a conspiracy to conceal to be inferred or implied from mere overt acts of concealment would result in a great widening of the scope of conspiracy prosecutions, since it would extend the life of a conspiracy indefinitely. Acts of covering up, even though done in the context of a mutually understood need for secrecy, cannot themselves constitute proof that concealment of the crime after its commission was part of the initial agreement among the conspirators. For every conspiracy is by its very nature secret; a case can hardly be supposed where men concert together for crime and advertise their purpose to the world. And again, every conspiracy will inevitably be followed by actions taken to cover the conspirators' traces. Sanctioning the Government's theory would for all practical purposes wipe out the statute of limitations in conspiracy cases, as well as extend indefinitely the time within which hearsay declarations will bind co-conspirators.

Grunewald, 353 U.S. at 402. The language in Yates was also quite cautious:

The Government contends that even if the trial court was mistaken in its construction of the statute, the error was harmless because the conspiracy charged embraced both 'advocacy' of violent overthrow and 'organizing' the Communist Party, and the jury was instructed that in order to convict it must find a conspiracy extending to both objectives. Hence, the argument is, the jury must in any event be taken to have found petitioners guilty of conspiring to advocate, and the convictions are supportable on that basis alone. We cannot accept this proposition for a number of reasons. The portions of the trial court's instructions relied on by the Government are not sufficiently clear or specific to warrant our drawing the inference that the jury understood it must find an agreement extending to both 'advocacy' and 'organizing' in order to convict. Further, in order to convict, the jury was required, as the court charged, to find an overt act which was 'knowingly done in furtherance of an object or purpose of the conspiracy charged in the indictment,' and we have no way of knowing whether the overt act found by the jury was one which it believed to be in furtherance of the 'advocacy' rather than the 'organizing' objective of the alleged conspiracy. The character of most of the overt acts alleged associates them as readily with 'organizing' as with 'advocacy.'

Yates, 354 U.S. at 311. 
disapprove the doctrine of emplied [sic] or constructive crime in its entirety and in every manifestation. And I think there should be no straining to uphold any conspiracy conviction where prosecution for the substantive offense is adequate and the purpose served by adding the conspiracy charge seems chiefly to get procedural advantages to ease the way to conviction. 4

No less a judicial luminary than Learned Hand had similar thoughts regarding the use of the conspiracy charge:

[S]o many prosecutors seek to sweep within the drag-net of conspiracy all those who have been associated in any degree whatever with the main offenders. That there are opportunities of great oppression in such a doctrine is very plain, and it is only by circumscribing the scope of such all comprehensive indictments that they can be avoided.

As has been chronicled many times, the conspiracy charge subjects offenders at trial to troubling procedural disadvantages,${ }^{6}$ the potential for harsh sentences if convicted of conspiracy, ${ }^{7}$ and liability for crimes

4. Krulewitch, 336 U.S. at 445 (Jackson, J., concurring). Justice Jackson referred to the cautionary report of the Conference of Senior Circuit Judges written in 1925:

We note the prevalent use of conspiracy indictments for converting a joint misdemeanor into a felony; and we express our conviction that both for this purpose and for the purpose — or at least with the effect — of bringing in much improper evidence, the conspiracy statute is being much abused.

'Although in a particular case there may be no preconcert of plan, excepting that necessarily inherent in mere joint action, it is difficult to exclude that situation from the established definitions of conspiracy; yet the theory which permits us to call the aborted plan a greater offense than the completed crime supposes a serious and substantially continued group scheme for cooperative law breaking. We observe so many conspiracy prosecutions which do not have this substantial base that we fear the creation of a general impression, very harmful to law enforcement, that this method of prosecution is used arbitrarily and harshly. Further the rules of evidence in conspiracy cases make them most difficult to try without prejudice to an innocent defendant.'

Id. at 446 n.2 (internal citation omitted).

5. United States v. Falcone, 109 F.2d 579, 581 (2d Cir. 1940).

6. This includes, among others, liberal venue principles, admissibility of declarations of coconspirators, and the joinder of both defendants and charges. I have discussed these problems on a number of occasions. See Paul Marcus, Re-Evaluating Large Multiple-Defendant Criminal Prosecutions, 11 WM. \& MARY BILl RTS. J. 67, 74 (2002); Paul Marcus, Criminal Conspiracy Law: Time to Turn Back from an Ever Expanding, Ever More Troubling Area, 1 WM. \& MARY BILL RTS. J. 1, 44-45 (1992); Paul Marcus, Conspiracy: The Criminal Agreement, in Theory and in Practice, 65 GEO. L.J. 925, 965-66 (1977) [hereinafter The Criminal Agreement].

7. Most United States jurisdictions penalize the convicted conspirator severely. To be sure, in a number of states, conspiracy carries a penalty that is the same as that for the most serious offense to which the defendant conspired to commit. See, e.g., 18 PA. Cons. STAT. § 905 (2014); WYO. STAT. ANN. § 6-1-304 (2015). The Supreme Court of the United States has long allowed consecutive sentences for the conspiracy crime and the substantive offense, which was the object of the agreement. As stated in Callanan v. United States:

The distinctiveness between a substantive offense and a conspiracy to commit is a 
committed by co-conspirators even without the actual aid of all those party to the pact. $^{8}$ There has been an intense and ongoing debate by scholars concerning the crime of conspiracy and whether the problems with it outweigh its benefits. Some have argued that there is little need for the crime. ${ }^{9}$ Others have questioned the broad application of the crime by the courts. ${ }^{10}$ Others have argued vigorously in support of the use of criminal conspiracy law. ${ }^{11}$ That debate has not, however, resonated with

postulate of our law. "If [sic] has been long and consistently recognized by the Court that the commission of the substantive offense and a conspiracy to commit it are separate and distinct offenses...." This settled principle derives from the reason of things in dealing with socially reprehensible conduct: collective criminal agreement-partnership in crime - presents a greater potential threat to the public than individual delicts.

364 U.S. 587, 593 (1961).

The defendants in most states can also receive consecutive sentences for convictions of both conspiracy and substantive offenses committed in furtherance of the scheme. See, e.g., Bishop v. State, 98 A.3d 317, 328 (Md. Ct. Spec. App. 2014); State v. Holliday, 982 A.2d 268, 270 (Conn. App. Ct. 2009); Byrom v. State, 978 So. 2d 689, 691 (Miss. Ct. App. 2008); State v. Ybarra, 830 P.2d 522, 527 (Idaho Ct. App. 1992); State v. Ballard, 439 A.2d 1375, 1380, 1390 (R.I. 1982). The Supreme Court in a case of broad significance held that defendants, in a single conspiracy, who were convicted of violating two related - but distinct-drug conspiracy statutes could be sentenced consecutively. See Albernaz v. United States, 450 U.S. 333, 343 (1981). This treatment in our nation is in striking contrast to that seen in other common law nations where conspiracy is not seen as especially important in criminal prosecutions. See, e.g., BRITISH LAW COMMISSION, REPORT ON CONSPIRACY AND CRIMINAL LAW REFORM, No. 76, 2-3 (HMSO, London, 1976); PETER GILlies, THE LAW of CRIMINAL ConsPiRACY, 256 (2d ed. 1990) ("obviously wrong [in Australia] to sentence [defendant] twice over for a conspiracy and for a substantive offence or offences committed pursuant to it").

8. Under the Pinkerton doctrine (accepted by most states and in the federal system), a defendant can be held responsible as a principal for all crimes committed by co-conspirators so long as "the substantive offense [is] committed by one of the conspirators... in furtherance of the conspiracy [unless those substantive offenses do] not fall within the scope of the unlawful project, or [were] merely a part of the ramifications of the plan which could not be reasonably foreseen as a necessary or natural consequence of the unlawful agreement." Pinkerton v. United States, 328 U.S. 640, 647-48 (1946). The range of this principle has been applied in breathtaking fashion in both the state and federal courts. It has allowed convictions for crimes such as armed robbery, United States v. Zackery, 494 F.3d 644, 649 (8th Cir. 2007); manslaughter, State v. Coward, 972 A.2d 691, 702-03 (Conn. 2009); and murder, People v. Zielesch, 101 Cal. Rptr. 3d 628, 636 (Cal. Ct. App. 2009).

9. Phillip E. Johnson, The Unnecessary Crime of Conspiracy, 61 CAL. L. REV. 1137, 1139-40 (1973) (positing that little would be lost for the government if the crime were to be wholly eliminated). In an earlier piece, I agreed with Professor Johnson's basic notion, but I contended that he went too far in calling for its elimination. See Marcus, The Criminal Agreement, supra note 6, at 966.

10. Steven R. Morrison, Requiring Proof of Conspiratorial Dangerousness, 88 TuL. L. REV. 483,513 (2014) (asserting that evidence is sparse as to whether agreements to commit crimes actually do create greater dangers justifying the crime of conspiracy).

11. Neal Kumar Katyal, Conspiracy Theory, 112 YALE L.J. 1307, 1309-10 (2003) (making the case for the necessity of using the charge broadly). The court in United States v. Hassan gave a spirited defense of the conspiracy offense, there in a terrorist prosecution:

Absent the long reach of the federal conspiracy statutes, the government would have been forced to pursue the appellants with one hand tied behind its back. No such constraint served to hinder the investigation and prosecution of the appellants, however, 
the Supreme Court for many years, and, in this Article, I do not intend to focus further on it.

For several decades now, one would be hard pressed to find any serious concerns expressed by justices as to the crime or the way in which conspiracy is prosecuted. To be sure, in virtually every major conspiracy case to come before the Court since 1987, the government has won convincingly - often times with nary a dissent. ${ }^{12}$ My own view is that the Supreme Court has unwisely embraced so enthusiastically both the conspiracy doctrine and the manner in which it is prosecuted. In the major conspiracy cases I discuss below, ${ }^{13}$ I contend that the prudent course here was not to do what the justices did: strongly support, in almost every instance, the government position and ignore the reach of

and we are reminded once more that the charge of conspiring to commit a federal crime has yet to relinquish its well-earned reputation as - in the words of Learned Hand - the "darling of the modern prosecutor's nursery." Judge Hand's profound observation is as true now as it was nearly ninety years ago.

Over the course of the modern legal era, the pursuit of federal conspiracy convictions has doubtlessly been a boon to United States Attorneys. And it is eminently fair and reasonable to say that the implementing statutes-particularly those that dispense with the commission of an overt act as an element of the crime-sometimes paint with a broad brush. But our system of government and law reposes great and solemn trust in federal prosecutors to exercise their discretion as instruments of right and justice, and it is therefore "for prosecutors rather than courts to determine when to use a scatter gun to bring down the defendant.",

Indeed, the societal utility of conspiracy prosecutions as a weapon against evildoers is manifest not merely in the substantive elements of the offense, but also in the procedural mechanisms enabling its ready proof, even against those only marginally involved. A person intending to only be "in for a penny," with the slightest connection to an established conspiracy, actually risks being "in for a pound." .. . Put succinctly, the specter of federal criminal liability cannot help but serve as an intense deterrent to those who otherwise would be bent on violence.

742 F.3d 104, 146 (4th Cir. 2014) (citations omitted).

12. I use 1987, just under thirty years ago, as the cut-off year for several reasons. That was the year William Rehnquist was elevated to Chief Justice. In the period since 1987, eighteen Justices served (or continue to serve) on the Court: Brennan, White, Marshall, Blackmun, Powell, Stevens, O’Connor, Scalia, Kennedy, Souter, Thomas, Ginsburg, Breyer, Roberts, Alito, Sotomayor, and Kagan, along with Rehnquist. The Justices came with diverse professional backgrounds including private practice, public practice, judging, and law teaching. This group was appointed by ten Presidents (Eisenhower, Kennedy, Johnson, Nixon, Ford, Reagan, G.H.W. Bush, Clinton, G.W. Bush, and Obama). This thirty-year period has seen remarkable growth in federal criminal jurisdiction, accompanied by equally remarkable shrinkage in the Supreme Court's docket. In 1987 the Court issued 187 substantive decisions. Opinions from 1987, JUSTIA.COM, https://supreme.justia.com/cases/federal/us/year/1987.html (last visited Sept. 24, 2015). In the 2014-15 term the number declined to 66 decisions. Opinions from 2014, JUSTIA.COM, https://supreme.justia.com/cases/federal/us/year/2014.html (last visited Sept. 24, 2015); Opinions from 2015, JUSTIA.COM, https://supreme.justia.com/cases/federal/us/year/2015.html (last visited Sept. 24, 2015).

13. Bourjaily v. United States, 483 U.S. 171 (1987). I note in Subsection II.e that Bourjaily is not truly a conspiracy ruling, even though the defendant was convicted on a conspiracy count. It is more properly seen as an evidence decision. 
the conspiracy offense, a reach which continues to expand. Moreover, it was not at all clear in these cases that an even-handed approach would have necessarily led to the broad reaffirmation of conspiracy doctrine and rules of practice. Still, in reading these cases, one is struck by just how strongly the Justices have spoken in supporting such prosecutions. It is to those cases, and the rationale for them, to which I will soon turn in this Article.

Before doing so, however, it should be noted that the selected cases for discussion are not the only conspiracy decisions of importance decided by the Supreme Court in this time period. I chose these five because of their impact on criminal conspiracy prosecutions nationwide. Other conspiracy rulings from the Court are not found here because:

- They are of somewhat more limited significance. Cases such as Rutledge v. United States ${ }^{14}$ fall into this grouping.

- They confused the law, offering little guidance to lawyers and judges. Certainly the two decisions applying the Bruton rule qualify. ${ }^{15}$

14. 517 U.S. 292 (1996). The question in Rutledge was whether it was improper to sentence the defendant to concurrent sentences for violations of a drug conspiracy (21 U.S.C. $§ 846$ (2012)) as well as for conducting a continuing criminal enterprise (21 U.S.C. $§ 848$ (2012)). Id. at 292. The Court held that it was, as "[a] guilty verdict on an $\S 848$ charge necessarily includes a finding that the defendant also participated in a conspiracy violative of $\S 846 . " I d$. at 307 . United States $v$. Jimenez Recio is also not of great practical significance. 537 U.S. 270 (2003). There the Justices struck down a lower court rule "that a conspiracy ends automatically when the object of the conspiracy becomes impossible to achieve..." Id. at 272. This rule, the Court found, is inconsistent with the rationale for the conspiracy offense.

The Court has repeatedly said that the essence of a conspiracy is "an agreement to commit an unlawful act." That agreement is "a distinct evil," which "may exist and be punished whether or not the substantive crime ensues." The conspiracy poses a "threat to the public" over and above the threat of the commission of the relevant substantive crime - both because the "[c]ombination in crime makes more likely the commission of [other] crimes" and because it "decreases the probability that the individuals involved will depart from their path of criminality." Where police have frustrated a conspiracy's specific objective but conspirators (unaware of that fact) have neither abandoned the conspiracy nor withdrawn, these special conspiracy-related dangers remain. So too remains the essence of the conspiracy - the agreement to commit the crime. That being so, the Government's defeat of the conspiracy's objective will not necessarily and automatically terminate the conspiracy.

Id. at 274-75 (citations omitted).

15. In Bruton v. United States, 391 U.S. 123, 124 (1968), a co-defendant's confession incriminated the appellant. The trial judge gave the jury a limiting instruction, saying that it should use the confession as evidence only against the declarant and not against the appellant, even though the appellant was named in the confession. Id. The Court held that the limiting instruction was insufficient to protect the appellant's confrontation right:

Here the introduction of Evans' confession posed a substantial threat to petitioner's right to confront the witnesses against him, and this is a hazard we cannot ignore. Despite the concededly clear instructions to the jury to disregard Evans' inadmissible hearsay 
- While conspiracy prosecutions, the ultimate decisions are more concerned with other bodies of law. Boyle v. United States $^{16}$ is just such a case.

\section{THE DECISIONS}

\section{A. Burden of Proof on Withdrawal; It Seems So Simple}

In its most recent substantive conspiracy decision, the Court in Smith v. United States ${ }^{17}$ had a seemingly simple task. All it had to do was restate the standard rule that withdrawal in a conspiracy case is an affirmative defense and find yet again that the burden of proof as to defenses is on the defendant unless otherwise legislatively determined. In a short, unanimous opinion written by Justice Scalia, that is precisely what the Court did. I believe, however, that the task was not so simple, and the hornbook law here is not so well-established as the opinion indicates.

evidence inculpating petitioner, in the context of a joint trial we cannot accept limiting instructions as an adequate substitute for petitioner's constitutional right of crossexamination.

Id. at 137. Gray v. Maryland, 523 U.S. 185, 188-89 (1998), and the earlier Richardson v. Marsh, 481 U.S. 200, 201-03 (1987), each applied Bruton to the situation in which the trial judge, in a joint trial, allowed the confession of one defendant, but then eliminated (redacted) the confession's reference to the non-declarant. To write that the two decisions are not exactly consistent, and offer little guidance, is to seriously understate the matter. In Gray the Court held that "a redaction that replaces a name with an obvious blank space or symbol or word such as "deleted" violates Bruton. Gray, 523 U.S. at 189. In Richardson, the ruling was different; there a redaction was allowed which "eliminate[d] not only the defendant's name, but any reference to his or her existence." Richardson, 481 U.S., at 211. Consistent and clear? Hardly. As one thoughtful commentator (a former student of this writer) wrote:

Jurors are human beings, and it is sometimes impossible for them to suppress their natural inclination to try to discover the identity of the redaction in a defendant's confession and to not use the confession as evidence against his codefendant. In attempting to protect the rights of defendants to cross-examine the witnesses against them, however, the Supreme Court has only muddied the waters as to how a confession of a codefendant may be introduced into evidence consistent with that right. It is of no comfort to say that simply severing the trials or refusing to use the confession is the solution to this problem, as these options may not be practical or may be overly burdensome to prosecutors or defendants in some circumstances. It is necessary, therefore, for the Court to finally and authoritatively settle the remaining issues that arise when the confession of a nontestifying codefendant is introduced into evidence in a joint trial.

Bryan M. Shay, "So I Says to 'The Guy,' I Says. . ": The Constitutionality of Neutral Pronoun Redaction in Multidefendant Criminal Trials, 48 WM. \& MARY L. REV. 345, 395 (2006).

16. 556 U.S. 938, 940-41 (2009). The decision focused principally on defining a key element of the RICO statute (Racketeer Influenced and Corrupt Organizations Act, 18 U.S.C. § 1962(c) (2012)), the definition of an association-in-fact "enterprise."

17. 133 S. Ct. 714 (2013). 
To understand this contrary view, one must look first to a few of the basics regarding the crime of conspiracy. As Smith quite properly noted, the essence of the crime is the agreement, "the combination of minds in an unlawful purpose."18 Moreover, as the opinion indicated, withdrawal traditionally has been seen as an affirmative defense, something that "does not negate an element of the conspiracy crimes charged."19 Finally, the courts have always determined that "[s]ince conspiracy is a continuing offense, a defendant who has joined a conspiracy continues to violate the law 'through every moment of [the conspiracy's] existence ....",20

It certainly seems routine enough to then conclude, as all nine Justices did, that withdrawal, like most defenses, requires the defendant to shoulder the burden of persuasion. I suggest, however, that this conclusion is neither certain nor routine because of the special role of withdrawal with the crime of conspiracy.

As with other inchoate offenses, typically-in many U.S. jurisdictions ${ }^{21}$ —once the elements of the crime have been achieved, there is no abandoning liability for that crime. ${ }^{22}$ Even in such a situation, however, withdrawal can be important for other reasons. If acts, crimes,

18. Id. at 719 .

19. Id.

20. Id. (citations omitted). And, of course, the conspirator "becomes responsible for the acts of his co-conspirators in pursuit of their common plot" id., under the rule established in Pinkerton $v$. United States, 328 U.S. 640 (1946). See discussion in supra note 8.

21. The Model Penal Code (MPC) would allow withdrawal for all three inchoate offenses. With attempt, § 5.01(4) of the MPC allows for what the drafters referred to as Renunciation of Criminal Purpose:

When the actor's conduct would otherwise constitute an attempt under Subsection (1)(b) or (1)(c) of this section, it is an affirmative defense that he abandoned his effort to commit the crime or otherwise prevented its commission, under circumstances manifesting a complete and voluntary renunciation of his criminal purpose. The establishment of such defense does not, however, affect the liability of an accomplice who did not join in such abandonment or prevention.

The language is similar with the crimes of solicitation, MPC $\S 5.02(3)$, and conspiracy. MPC $\S$ 5.03(6) (1985). Many states have adopted some, or all, of these provisions. One commentator recently noted that with the crime of attempt, slightly more than half the "jurisdictions in the United States follow the Model Penal Code approach in allowing an affirmative defense of abandonment." Gideon Yaffe, Criminal Attempts, 124 YALE L.J. 92, 142 (2014). A few examples of the MPC approach are Ky. REV. STAT. ANN. § 506.020 (West 2015), OR. REV. STAT. § 161.430 (2015), and 18 PA. CONS. STAT. § 901(c) (1973).

22. Many jurisdictions hold that one cannot abandon an attempt once the action (substantial step, action in close proximity to the completed crime, etc.) has been taken. See, e.g., State v. Robins, 646 N.W.2d 287, 295 (Wis. 2002); People v. Herman, 119 Cal. Rptr. 2d 199, 215 (Cal. Ct. App. 2002). That would also be true of solicitation, once the act of encouragement or aid has been taken. See e.g., State v. Lynch, 125 P.3d 1148, 1150 (Mont. 2005); People v. Manetas, No. 198568, 1998 Mich. App. LEXIS 1845, at *4 (Mich. Ct. App. July 7, 1998); Moran v. Schwarz, 826 P.2d 952, 954 (Nev. 1992). 
or declarations of co-conspirators occur after withdrawal, they will not be admissible against the defendant who is no longer part of the pact. And, as in Smith, withdrawal can be of crucial significance with a statute of limitations claim. ${ }^{23}$ With such a claim, the defendant is asserting that he cannot be found guilty of the crime of conspiracy, for the government did not move against her during the statutory period. The Justices saw that as a classic affirmative defense, so that the burden of proving withdrawal may quite properly be placed on the defendant. ${ }^{24}$ "Thus, although union of withdrawal with a statute-of-limitations defense can free the defendant of criminal liability, it does not place upon the prosecution a constitutional responsibility to prove that he did not withdraw. As with other affirmative defenses, the burden is on him." 25

Others, however, took a quite different view of the role being played with withdrawal and the statutory period. Probably the strongest judicial statement of this position ${ }^{26}$ was made by the Seventh Circuit in United States $v$. Read. ${ }^{27}$ The court there focused its attention on two related, but

23. The oddity in Smith is that the defendant did not ask for a jury instruction on point. Rather, "[a]fter it began deliberations, the jury asked the court what to do in the event that a defendant withdrew from the conspiracies outside the relevant limitations period." Smith v. United States, 133 S. Ct. 714, 718 (2013).

24. As opposed to claims that relate to elements of the crime, though they may seemingly appear not to. The most prominent illustration is Mullaney v. Wilbur, 421 U.S. 684, 687-88 (1975) where the instruction in a murder case was found to violate due process because it placed onto the defendant the burden to prove that he acted in the heat of passion upon sudden provocation thus bringing the crime down to voluntary manslaughter. This was so because heat of passion was actually an element of the manslaughter crime; a negative element, but an element nevertheless. Id. at 703. But see Patterson v. New York, 432 U.S. 197, 228-30 (1977) (limiting the holding in Mullaney to the second degree murder/voluntary manslaughter situation).

25. Smith, 133 S. Ct. at 720 . The Court explained further:

Allocating to a defendant the burden of proving withdrawal does not violate the Due Process Clause. While the Government must prove beyond a reasonable doubt "every fact necessary to constitute the crime with which [the defendant] is charged," "[p]roof of the nonexistence of all affirmative defenses has never been constitutionally required." The State is foreclosed from shifting the burden of proof to the defendant only "when an affirmative defense does negate an element of the crime." Where instead it "excuse[s] conduct that would otherwise be punishable," but "does not controvert any of the elements of the offense itself," the Government has no constitutional duty to overcome the defense beyond a reasonable doubt.

Id. at 719 (citations omitted) (emphasis in original). Of course, all this makes sense if conspiracy is thought of necessarily as a continuing offense. In such a situation, "[w]ithdrawal does not negate an element of the conspiracy crimes charged here." Id. As the court in Read pointed out, infra, another view of the matter is to see that the government has the burden of showing defendant's membership in the conspiracy at the time of the charge. United States v. Read, 658 F.2d 1225, 1232 (7th Cir. 1981).

26. For strong commentary in support of this position, see Linda Cantoni, Note, Withdrawal from Conspiracy: A Constitutional Allocation of Evidentiary Burdens, 51 FoRDHAM L. REV. 438, 439-40 (1982).

27. 658 F. $2 \mathrm{~d}$ at 1233 . 
distinct, points. ${ }^{28}$ The first was the history of withdrawal and the notion that the defendant has always had to prove her voluntary, timely, and legally adequate abandonment of the endeavor. ${ }^{29}$ This notion is cited repeatedly by both state and federal courts, ${ }^{30}$ relying almost entirely on an early Supreme Court decision dealing principally with venue in conspiracy cases, Hyde v. United States. ${ }^{31}$ As Judge Bauer, for the Read panel, showed rather persuasively, however, Hyde does not stand for that proposition:

The government, however, insists that Hyde v. United States, a long-established Supreme Court case, placed the burden of proving withdrawal on the defendant. Indeed, Hyde has often been cited for that proposition in the courts of appeals. Almost every case we researched holds that the burden is on the defendant to "prove" or "establish" withdrawal. Within this Circuit, we recently held that it "is well-settled (that) this burden of establishing withdrawal lies on the defendant."

We have, however, reexamined Hyde. Our research convinces us that the cases, including our own, have misinterpreted Hyde. According to our interpretation, Hyde placed only the burden of going forward on the defendant.... Hyde said nothing explicit about the amount of evidence the defendant must offer to show "some act to disavow or defeat the purpose" of the conspiracy. As one commentator noted, the Hyde language "might have been interpreted as merely shifting the production burden on the issue of withdrawal to the defendant, and leaving the persuasion burden with the state."32

The Supreme Court in Smith ignored this argument entirely.

The second point from Read is that under classic rules of substantive criminal law, the burden of persuasion (as opposed to the burden of production-coming forth with some credible evidence) regarding elements of a crime cannot be on the defendant, as a matter of constitutional law and policy. ${ }^{33}$ As to elements of a charged crime, the requirement is that the government show that during the appropriate time

\footnotetext{
28. Id. at $1232-33,1236$.

29. Id. at $1232-36$.

30. Including in the Smith opinion: "Petitioner's claim that assertion of a statute-of-limitations defense shifts that burden is incompatible with the established proposition that a defendant's membership in the conspiracy, and his responsibility for its acts, endures even if he is entirely inactive after joining it." Read, 133 S. Ct. at 721. See also Hyde v. United States, stating "[a]s he has started evil forces, he must withdraw his support from them or incur the guilt of their continuance." 225 U.S. 347, 369-70 (1912).

31. 225 U.S. at 369.

32. Read, 658 F.2d at $1233-34$ (citations omitted).

33. Id. at 1232 .
} 
(under the statute of limitations) the defendant charged with conspiracy actually was a member of that conspiracy, as the Read court explained:

A subtle, but important, change was occurring. Within decades, the Hyde rule that a defendant show some "affirmative action" to trigger the withdrawal defense was transformed into a rule that the defendant must meet "rigorous requirements" to show his withdrawal [the Read court here noted that earlier cases to the contrary were ignored or distinguished]. Present law now states the burden of establishing withdrawal lies on the defendant.

The withdrawal rule is based on a misinterpretation of Hyde's requirement that the defendant do "some act to disavow or defeat the purpose" of the conspiracy to withdraw. We have traced back the citation of authority in our own cases; they lead back to only the same language in Hyde.

As withdrawal negates the essential element of membership, it must be disproved beyond a reasonable doubt by the government. We therefore overrule those cases imposing the burden of proving withdrawal on the defendant. We hold today that the burden of going forward with evidence of withdrawal and with evidence that he withdrew prior to the statute of limitations remains on the defendant. However, once he advances sufficient evidence, the burden of persuasion is on the prosecution to disprove the defense of withdrawal beyond a reasonable doubt. ${ }^{34}$

This is a strong argument on the misreading of earlier precedent and the due process requirement. The Supreme Court once again ignored the assertion entirely.

Having noted concern with the Court's handling of the arguments in Smith, let me hasten to note that it is not clear to me that the defendant's position is necessarily the correct one, as withdrawal in some respects does look like a classic affirmative defense. ${ }^{35}$ Still, to see this short, unanimous ruling wholly ignoring some serious arguments is troubling indeed. ${ }^{36}$ The decision is dismissive of serious assertions, looking to the danger posed by the conspiracy:

Having joined forces to achieve collectively more evil than he could accomplish alone, Smith tied his fate to that of the group. His individual change of heart (assuming it occurred) could not put the

\footnotetext{
34. Id. at $1235-36$ (citations omitted).

35. As the Smith Court wrote. 133 S. Ct. at 720.

36. Particularly in a case in which the defendant had spent the last six years of the charged conspiracies in prison for a felony conviction. Id. at 718. The applicable statute of limitations, 18 U.S.C. $§ 3282$ (2012), is five years.
} 
conspiracy genie back in the bottle. We punish him for the havoc wreaked by the unlawful scheme, whether or not he remained actively involved. It is his withdrawal that must be active, and it was his burden to show that.

\section{B. Burdens of the Conspiracy, But Not the Benefits}

Let us consider two conspirators driving in a car and transporting illegal guns. Our conspirator is in the vehicle of her co-conspirator. They are acting in furtherance of the pact, are transporting incriminating evidence, and they are stopped by the police. The stop is in violation of the Fourth Amendment. The co-conspirator/owner and driver of the car moves to suppress the evidence, and his motion is granted. The conspirator/passenger also moves to suppress; her motion is denied.

As has been stated repeatedly over decades, "[a] conspiracy is a kind of criminal partnership." 38 As such, this grouping together subjects conspirators to broad and early liability as to crimes, acts and statements of other conspirators, as noted above. Just as clear is the notion of standing under the Fourth Amendment. ${ }^{39}$ The defendant in making a challenge to a search or seizure must demonstrate some individual interest: "a violation occurs when government officers violate a person's

37. Smith, 133 S. Ct. at 721.

38. Sixth Circuit Committee on Pattern Criminal Jury Instructions, Pattern Criminal Jury Instructions, $\quad \S \quad 3.01 \mathrm{~A}(2)$, http://www.ca6.uscourts.gov/internet/crim_jury_insts/pdf/crmpattjur_full.pdf. $\quad$ For a detailed discussion of the agreement requirement and the manner of proof, see PAUL MARCUS, THE Prosecution and Defense of Criminal Conspiracy Cases $\$ \S 2.01-.10$ (Matthew Bender \& Co., Inc.) (2015).

39. Former Chief Justice Rehnquist railed against the use of the term, preferring instead to focus on concepts of individual privacy. In Rakas $v$. Illinois, he wrote: "[W]e are not at all sure that the determination of a motion to suppress is materially aided by labeling the inquiry ... as one of standing, rather than simply recognizing it as one involving the substantive question of whether or not the proponent of the motion to suppress has had his own Fourth Amendment rights infringed by the search and seizure which he seeks to challenge." 439 U.S. 128, 133 (1978). In spite of the critique, standing remains the key term in use. One commentator explained:

Over the last forty years, the Supreme Court has worked out a series of principles for when a defendant has standing to object to the Fourth Amendment search of someone else's property. According to the those [sic] cases, the key issue is whether the government violated the defendant's own reasonable expectation of privacy.... The owner, legitimate renter, or legitimate repeated borrower of a car generally has standing to object to a search of it. A person who steals a car or drives it in violation of a rental contract does not.

Orin Kerr, Does Fourth Amendment Standing Work Differently for Jones Trespass Searches, Traditional Katz Searches, and Long-term Katz Searches?, THE VolOKH CONSPIRACY (Feb. 14, 2012, 10:30 PM), http://volokh.com/2012/02/14/does-fourth-amendment-standing-work-differentlyfor-jones-trespass-searches-traditional-katz-searches-and-katz-long-term-expectation-of-privacysearches/. 
'reasonable expectation of privacy.",40

In United States v. Padilla, ${ }^{41}$ the government prosecutor sought to prove the conspiracy case against one conspirator based on the allegedly unlawful search of the car driven by another conspirator and owned by still another conspirator. ${ }^{42}$ Padilla argued that because he was in the conspiracy with the others, the car contained items intended to further the conspiracy, and he was being charged in a conspiracy with those other individuals, he ought to be able to challenge the search (and resulting evidence) by the officer. ${ }^{43}$ The Ninth Circuit viewed the conspiracy theory as trumping the standing rule and allowed the challenge. The judges there made the point that "a coconspirator's participation in an operation or arrangement that indicates joint control and supervision of the place searched establishes standing." 44

In another short per curiam opinion, a unanimous Supreme Court rejected the "conspiracy equals standing" view of the court of appeals. ${ }^{45}$ The opinion dealt firmly with the matter:

The "coconspirator exception" developed by the Ninth Circuit is, therefore, not only contrary to [an earlier holding], but at odds with the principle discussed above. Expectations of privacy and property interests govern the analysis of Fourth Amendment search and seizure claims. Participants in a criminal conspiracy may have such expectations or interests, but the conspiracy itself neither adds to nor detracts from them. Neither the fact, for example, that Maria Simpson was the "communication link" between her husband and the others, nor the fact that Donald Simpson and Xavier Padilla were in charge of transportation for the conspirators, has any bearing on their respective Fourth Amendment rights.

For the Justices, the concept of agreement and joint liability was simply irrelevant to the Fourth Amendment questions: did the petitioner have "[an] ownership interest in the [property seized] [or a] legitimate

40. United States v. Jones, 132 S. Ct. 945, 950 (2012) (quoting Katz v. United States, 389 U.S. $347,360(1967))$.

41. 508 U.S. 77 (1993).

42. Id. at $78-80$.

43. Id. at $79-81$.

44. United States v. Padilla, 960 F.2d 854, 859 (9th Cir. 1992), rev'd, 508 U.S. 77 (1993) (citation omitted). The principle could have been stated even more broadly, finding standing anytime evidence was offered against any conspirator based on an allegedly unconstitutional search or seizure of property of another conspirator, which contained items intended to further the conspiracy.

45. Padilla, 508 U.S. at 82 .

46. Id. 
expectation of privacy in the area searched ...."47 Irrelevant? I am not so sure. After all, the concept of agreement can tremendously affect sentences, location of prosecutions, size of trials, and evidence being offered. If used there, why not have at least a serious discussion of why the fact of agreement does not also impact on the nature of the government investigation resulting in highly prejudicial evidence? Calling for symmetry between the burdens of conspiracy law and this one benefit might well be viewed as appropriate and in keeping with an even handed set of prosecution principles. The unanimous Supreme Court was not persuaded.

\section{Overt Act Not Required}

The general U.S. conspiracy statute, 18 U.S.C. § 371, expressly requires an overt act requirement ("If two or more persons conspire ... and one or more of such persons do any act to effect the object of the conspiracy"). ${ }^{48}$ Some other federal conspiracy statutes do not have explicit overt act requirements. At issue in United States v. Shabani was one such law, involving a conspiracy to distribute cocaine. ${ }^{49}$ Section 846 of Title 21 of the United States Code states that it is a crime if "[a]ny person . . . conspires." 50 There is no mention of any sort of needed act in furtherance of that pact. ${ }^{51}$ The question before the Court was whether the silence of Congress in $\S 846$ was purposeful so that the essential—indeed the only necessary-element of proof was an agreement. Or, did silence show that Congress had not considered the matter so that a reasonable construction of $\S 846$ would be to make it consistent with $\S 371$, mandating such an act? $?^{52}$

\footnotetext{
47. $I d$.

48. 18 U.S.C. $\$ 371(2012)$.

49. 513 U.S. 10 (1994).

50. 21 U.S.C. $\S 846$ (2012).

51. See id.

52. A follow-up case, Whitfield $v$. United States, raised the same question, though dealing with 18 U.S.C. $\$ 1956$ (h), conspiracy to commit money laundering. 543 U.S. 209 (2005). The answer of the Court was the same - no overt act requirement:

Shabani distilled the governing rule for conspiracy statutes as follows: "Nash and Singer give Congress a formulary: by choosing a text modeled on $\S 371$, it gets an overtact requirement; by choosing a text modeled on the Sherman Act, 15 U.S.C. $\$ 1$ [which, like 21 U.S.C. $\$ 846$, omits any express overt-act requirement], it dispenses with such a requirement." This rule dictates the outcome in the instant cases as well: Because the text of $\S 1956(\mathrm{~h})$ does not expressly make the commission of an overt act an element of the conspiracy offense, the Government need not prove an overt act to obtain a conviction.

Id. at 214 (citations omitted). Lower courts have followed with other federal conspiracy statutes.
} 
Once again, a unanimous Court found for the government. Indeed, the Justices had little difficulty in finding that the government would not need to prove an overt act in order to have a conspiracy conviction, under $\S 846$. Justice O'Connor gave several reasons for this conclusion. First, she dealt with the intent of Congress:

Congress appears to have made the choice [to omit an overt act requirement] quite deliberately with respect to $\S 846$; the same Congress that passed this provision also enacted the Organized Crime Control Act of 1970 of which contains an explicit requirement that "one or more of the [conspirators] does any act to affect the object of such a conspiracy.",53

That Congress did in fact distinguish between the two conspiracy statutes is beyond debate. That members of Congress actually considered this distinction and knowingly chose to treat $\S 846$ differently is another matter. A careful review of the legislative history for both statutes finds no mention of an overt act requirement either in committee reports or in statements on the floor of Congress. Congress truly was silent on this point.

Second, the Justices looked to their long-standing tradition of statutory construction whereby, "absent contrary indications, Congress intends to adopt the common law definition of statutory terms." could not argue with this well-established convention that has been applied quite a number of times. ${ }^{55}$

On its face, the decision reached here is neither a surprise nor a mystery. The opinion is short, it cites well-regarded precedent, and it sticks closely to the careful reading of legislative language. It is, nevertheless, troublesome for a few reasons. Let me hasten to point out that it is not difficult because of the practical impact of the determination. No, whether a conspiracy statute has an overt act element or not will hardly matter in many cases. I explored the reason for this

The most recent case is United States v. Roy, 783 F.3d 418, 420 (2d Cir. 2015) (conspiracy to commit wire fraud, 18 U.S.C. $\$ 1349$ (2006)).

53. Shabani, 513 U.S. at 14 (first alteration added) (citations omitted).

54. Id. at 13 .

55. See Molzof v. United States, 502 U.S. 301, 307-08 (1992) (Federal Tort Claims Act); Singer v. United States, 323 U.S. 338, 339-40 (1945) (Selective Service Act); Nash v. United States, 229 U.S. 373, 378 (1913) (Sherman Antitrust Act). This rule has been followed in recent times as well in cases such as: United States v. Castleman, 134 S. Ct. 1405, 1409-10 (2014) (possession of firearms by one convicted of "a misdemeanor crime of domestic violence"); Sekhar v. United States, 133 S. Ct. 2720, 2724 (2013) (violation of the Hobbs Act); Clackamas Gastroenterology Assocs., P.C. v. Wells, 538 U.S. 440, 444-45 (2003) (coverage under Americans with Disabilities Act). All cases in this footnote were cited in the opinion. 
long ago in an empirical study funded by the National Science Foundation. There I looked to this question, among others: what is the impact of an overt act requirement? Repeatedly then - and since-the consistent response was that it basically had no impact at all.

Conversations with prosecutors confirmed this:

One stated that, "[n]o one will prosecute a case without an overt act; generally there is at least an attempt unless you have an informant which is the rare situation, for you find out about the conspiratorial relationship from the overt act." Another said that "[m]ost all conspiracies [charged] do usually involve substantial steps."

... The indication that prosecutors generally do not charge conspiracy in the purely inchoate situations is shown further by the prevailing view that requiring a substantial overt act would cause no more than a small reduction in the number of convictions .... Some prosecutors with whom I spoke expressed concern about requiring a substantial overt act, but they do not believe that many conspiracy charges involve insignificant overt acts. ${ }^{56}$

The true concern is not how Shabani will affect future rulings. Instead, it goes to a somewhat dismissive attitude of the Justices toward the very real problems inherent in the conspiracy charge and a change in direction from previous and far more sensitive views regarding prosecutorial overreach in this area.

As noted above ${ }^{57}$ decades earlier the Court in Grunewald was quite reluctant to define the conspiracy doctrine so as to allow for implied agreements to conceal, thereby extending relevant statute of limitations periods. Justice O'Connor acknowledged Grunewald in the Shabani opinion but did not call out the broad language of the earlier Court, or its much more narrow view of the conspiracy charge. And, there certainly was no reference in Shabani to the concurring opinion of Justice Jackson in Krulewitch sounding the alarm about the conspiracy charge. ${ }^{58}$ Quite the contrary:

Respondent contends that these decisions were rendered in a period of unfettered expansion in the law of conspiracy, a period which allegedly ended when the Court declared that "we will view with disfavor attempts to broaden the already pervasive and wide-sweeping nets of conspiracy prosecutions." Grunewald, however, was a statute of limitations case, and whatever exasperation with conspiracy

56. Conspiracy: The Criminal Agreement, in Theory and in Practice, supra note 6, at 930-32.

57. See supra note 3 .

58. See supra text accompanying note 4 . 
prosecutions the opinion may have expressed in dictum says little about the views of Congress when it enacted $\S 846 .{ }^{59}$

That, though, hardly tells the full story of Grunewald. Justice Harlan, there for the majority, expressed serious reservations about the government's use of the conspiracy charge:

Prior cases in this Court have repeatedly warned that we will view with disfavor attempts to broaden the already pervasive and widesweeping nets of conspiracy prosecutions. The important considerations of policy behind such warnings need not be again detailed. It is these considerations of policy which govern our holding today. As this case was tried, we have before us a typical example of a situation where the Government, faced by the bar of the three-year statute, is attempting to open the very floodgates against which Krulewitch warned. We cannot accede to the proposition that the duration of a conspiracy can be indefinitely lengthened merely because the conspiracy is kept a secret, and merely because the conspirators take steps to bury their traces, in order to avoid detection and punishment after the central criminal purpose has been accomplished. ${ }^{60}$

And Grunewald was not the only case showing disquiet among the Justices regarding the use of the conspiracy charge. Lutwak v. United States $^{61}$ is another. There, in a decision looking to whether declarations of co-conspirators were made during the course of the conspiracy, the Court wrote:

In the trial of a criminal case for conspiracy, it is inevitable that there shall be, as there was in this case, evidence as to declarations that is admissible as against all of the alleged conspirators; there are also other declarations admissible only as to the declarant and those present who by their silence or other conduct assent to the truth of the declaration. These declarations must be carefully and clearly limited by the court at the time of their admission and the jury instructed as to such declarations and the limitations put upon them. Even then, in most instances of a conspiracy trial of several persons together, the application of the rule places a heavy burden upon the jurors to keep in mind the admission of certain declarations and to whom they have been restricted and in some instances for what specific purpose. While these difficulties have been pointed out in several cases, the rule has nonetheless been applied. ${ }^{62}$

59. Shabani, 513 U.S. at 14 (citation omitted).

60. Grunewald v. United States, 353 U.S. 391, 404-05 (1957) (italics added) (citation omitted).

61. 344 U.S. 604 (1953).

62. Id. at 618-19 (citations omitted). 
Yet again, in Kotteakos v. United States, ${ }^{63}$ this unease came through, there with an appeal contending that while one conspiracy was charged, in fact multiple conspiracies were proven at trial:

There are times when of necessity, because of the nature and scope of the particular federation, large numbers of persons taking part must be tried together or perhaps not at all, at any rate as respects some. When many conspire, they invite mass trial by their conduct. Even so, the proceedings are exceptional to our tradition and call for use of every safeguard to individualize each defendant in his relation to the mass. Wholly different is it with those who join together with only a few, though many others may be doing the same and though some of them may line up with more than one group.

Criminal they may be, but it is not the criminality of mass conspiracy. They do not invite mass trial by their conduct. Nor does our system tolerate it. That way lies the drift toward totalitarian institutions. True, this may be inconvenient for prosecution. But our Government is not one of mere convenience or efficiency. It too has a stake, with every citizen, in his being afforded our historic individual protections, including those surrounding criminal trials. About them we dare not become careless or complacent when that fashion has become rampant over the earth. ${ }^{64}$

The language of Justices Harlan, Minton, and Rutledge in these cases signals deep hesitation about the conspiracy charge and the way in which it can unfairly affect the accused conspirator. Language that is direct and open-language that is simply not found in Shabani.

In addition, while the Court in Shabani was correct in noting that the common law did not require an overt act, the conspiracy crime in both England and the U.S. under the early common law was quite a limited offense. $^{65}$ As the scope of the crime broadened, the overt act element appeared more and more in the states as well as in the federal system. ${ }^{66}$ And, for good reason, the overt act serves a significant purpose in at least some cases. It is there to be sure that-with the limited proof needed to show agreement ${ }^{67}$-there is a true danger created by the pact, to show

63. 328 U.S. 750 (1946).

64. Id. at 773 .

65. See Paul Marcus, The Prosecution and Defense of Criminal Conspiracy Cases, $\S \S 1.01-.05$ (Matthew Bender \& Co. 2015).

66. The language is usually something like "an overt act," (see, e.g., 8 GUAM CODE ANN. § 95.30 (2014)), "some act" (see, e.g., CAL. PENAL CODE $§ 184$ (West 2012)), or "any act" (the general federal statute, 18 U.S.C. $\S 371$ (2012), uses this term, as do several state statutes such as W. VA. CODE ANN. § 61-10-31 (West 2002)), in furtherance of the agreement.

67. See infra text accompanying notes $62-66$. 
that there is a criminal endeavor "still at work." 68

Two earlier Justices of the Supreme Court did not downplay the importance of the overt act. For Chief Justice Vinson (then sitting as a Circuit Judge), "[t]he statutory crime differs from common-law conspiracy in that it requires an overt act. That is made an essential to give the conspirators a time, a place, and a chance to say that although we did agree, now that we are about to start, let's call it off." 69 As stated by Justice Harlan, "[t]he function of the overt act in a conspiracy prosecution is simply to manifest 'that the conspiracy is at work,' and is neither a project still resting solely in the minds of the conspirators nor a fully completed operation no longer in existence.,"70

One sees no such discussion by Justice O'Connor as to the importance of an overt act requirement. That failure is all the more telling considering how little is needed for the government to prove the agreement, the "essence" of the crime. ${ }^{71}$ "An agreement need not be explicit; a tacit agreement may support a conspiracy conviction." 72 As the Supreme Court itself noted, "Participation in a criminal conspiracy need not be proved by direct evidence; a common purpose and plan may be inferred from a 'development and collocation of circumstances.",73 And "the government is entitled to prove its case solely through circumstantial evidence." ${ }^{74}$ While the nature of the evidence needed for the government's case in conspiracy prosecutions has been sharply critiqued, ${ }^{75}$ few observers would doubt the breadth of the conspiracy

68. State v. Heitman, 629 N.W.2d 542, 553 (Neb. 2001) (quoting State v. Hansen, 562 N.W.2d 840, 849 (Neb. 1997)).

69. United States v. Offut, 127 F.2d 336, 338 (D.C. Cir. 1942).

70. Yates v. United States, 354 U.S. 298, 334 (1957) (citation omitted), overruled by Burks v. United States, 437 U.S. 1 (1978).

71. United States v. Martin, 618 F.3d 705, 735 (7th Cir. 2010).

72. United States v. Handlin, 366 F.3d 584, 589 (7th Cir. 2004) (internal citation omitted).

73. Glasser v. United States, 315 U.S. 60, 80 (1942) (internal citation omitted), superseded by statute, FED. R. EvID. 104(a), as recognized in Bourjaily v. United States, 483 U.S. 171 (1987). As stated in Ladd v. State, "the agreement to commit the criminal act "need not be formal or express, but may be inferred from the circumstances, particularly by declarations, acts, and conduct of the alleged conspirators." 87 So. 3d 1108, 1113 (Miss. Ct. App. 2012).

74. United States v. Pica, 692 F.3d 79, 86 (2d Cir. 2012) (internal citation omitted). Numerous cases so hold. See, e.g., United States v. Arrellano, 757 F.3d 623, 633 (7th Cir. 2014) ("A jury is not limited to direct evidence and may find an agreement to conspire based upon circumstantial evidence and reasonable inferences drawn from the relationship of the parties, their overt acts, and the totality of their conduct." (citing United States v. Wantuch, 525 F.3d 505, 519 (7th Cir. 2008)). Some pattern jury instructions also make this point. See, e.g., § 5.1 Conspiracy ( $\$ 53 a-48), 5$ Conn. Prac., Criminal Jury Instructions $\S 5.1$ (4th ed.) ("Circumstantial evidence is sufficient to prove that there was an agreement between, because conspiracies by their very nature, are formed in secret and only rarely can be proven other than by circumstantial evidence.").

75. See supra notes 9 and 10. 
charge. All the more reason, then, to have at least some discussion as to whether it would be appropriate to consider the wisdom of implying an overt act requirement to a conspiracy statute. One finds no such discussion in Shabani.

\section{The Nonhearsay Hearsay Exception ${ }^{76}$}

We turn now to a case that is highly significant and well known especially - and properly so - for its focus on one rule of evidence. The case, quite familiar to most who work on white collar crime and organized drug prosecutions, is Bourjaily v. United States. ${ }^{77}$ The Chief Justice there, over a vigorous dissent by Justice Blackmun, ${ }^{78}$ wrote of the reach of Federal Rule of Evidence 801(d)(2)(E), the traditional coconspirator hearsay exception. While an evidentiary ruling, it is extremely important in conspiracy prosecutions. To be sure, it is difficult to imagine many such prosecutions in which the exception is not raised at some point. Before looking at the decision, though, a few preliminary observations are necessary regarding the rule.

The co-conspirator hearsay exception is certainly not new to conspiracy prosecutions. For decades the United States Supreme Court has discussed it ${ }^{79}$ and for good reason: the co-conspirator rule likely is, as pointed out by Justice Powell, "the most frequently used exception to the hearsay rule." ${ }^{~}$ The rule can be stated simply: an out-of-court statement offered at trial to prove the truth of the statement is not excluded by

76. With thanks to my colleague Jeff Bellin for his helpful comments on the evidence materials in this section.

77. 483 U.S. 171 (1987).

78. Joined by Justices Brennan and Marshall. Justice Stevens concurred specially.

79. Indeed, for well over one-half century commentators have analyzed the Court's rulings about the exception. For one of the earliest, and best, looks, see Joseph H. Levie, Hearsay and Conspiracy: A Reexamination of the Co-Conspirators' Exception to the Hearsay Rule, $52 \mathrm{MICH}$. L. REV. 1159 (1954).

80. United States v. Inadi, 475 U.S. 387, 398 (1986). The principle surrounding co-conspirator declarations actually no longer arises as an exception to hearsay. It is, instead, denominated by Congress and many state legislatures to be non-hearsay. However, almost no one [including members of the Supreme Court] would refer to this in any way other than as a hearsay exception. Moreover, as noted by one federal judge, "[ $t]$ he distinction between a statement which is not hearsay and a statement which is an exception to the hearsay rule is semantic and is not determinative of the outcome of this case." United States v. Smith, 578 F.2d 1227, 1231 n.6 (8th Cir. 1978) (citation omitted). Others have been far less generous in noting the Congressional action. As one judge wrote, soon after the enactment of the federal rules: "[i]n that new code, the admissibility of the hearsay statements of a co-conspirator was codified, by a legislative finding that such statements are not hearsay. Like Humpty Dumpty in "Through the Looking Glass," a legislative body, when it uses a word such as "hearsay," can make that word mean what it wants it to mean." United States v. Buettner-Janusch, 500 F. Supp. 1285, 1292 (S.D.N.Y. 1980) (emphasis added). 
hearsay considerations if that statement was made by a conspirator during the course of the conspiracy and in furtherance of it. ${ }^{81}$ This rule is simple to state, but it is often difficult to apply - as we shall see. But, first, a notation is necessary to show that the rule is significant not just because it comes up so often. There are other reasons, as well. "[A] coconspirator's statement is admissible as if it were the defendant's own statement. ${ }^{" 82}$ Moreover, the statement will be admissible upon a theory of a joint venture, even though no conspiracy has been charged. ${ }^{83}$ In addition, a trial judge may allow the statement to be heard by the jury even before enough evidence has been offered to show the rule has been satisfied. ${ }^{84}$

The majority in Bourjaily construed a few different sections of the Federal Rules of Evidence in answering three questions brought before it. ${ }^{85}$ Only one is especially worthy of consideration here, and that relates to the use of the disputed statement itself. Years earlier, the Court determined that the declaration could not be used to establish the basis of the co-conspirator hearsay exception - that there was an ongoing conspiracy to which the declaration related. ${ }^{86}$ The Justices there, in the

81. FED. R. EVID. 801(d)(2)(E) provides that a statement "made by [a defendant]'s coconspirator during [the course of] and in furtherance of the conspiracy" may be introduced as nonhearsay. In addition to the federal rule, many states have similar rules (often with the same numbering system). See, e.g., IowA R. EvID. 5.801(d)(2)(E); N.H. R. EvID. 801(d)(2)(E); N.C. R. EVID. 801(d)(E).

82. United States v. Blair, No. 1:06-CR-39-TLS, 2006 WL 3392941, at *2 (N.D. Ind. Nov. 22, 2006).

83. State v. Hudson, 775 N.W.2d 429, 436 (Neb. 2009); United States v. Gewin, 471 F.3d 197, 201 (D.C. Cir. 2006); Byrd v. State, 187 S.W.3d 436, 440 (Tex. Crim. App. 2005).

84. It can be admitted "provisionally," subject to connection. Commonwealth v. Feliciano, 67 A.3d 19, 27 (Pa. Super. Ct. 2013); United States v. Ciresi, 697 F.3d 19, 25 (1st Cir. 2012); United States v. Brockenborrugh, 575 F.3d 726, 735-36 (D.C. Cir. 2009). If it is not ultimately connected, the jury can be instructed to disregard the statement. In rare cases, the judge can then order a mistrial. United States v. Loza, 763 F. Supp. 2d 108, 112 (D.D.C. 2011).

85. Here are the three questions:

(1) whether the court must determine by independent evidence that the conspiracy existed and that the defendant and the declarant were members of this conspiracy; (2) the quantum of proof on which such determinations must be based; and (3) whether a court must in each case examine the circumstances of such a statement to determine its reliability.

Bourjaily v. United States, 483 U.S. 171, 173 (1987). It is the first question at issue here. The second question was not terribly controversial. In line with the strong majority of courts, the usual standard of preponderance of the evidence was tagged. As to the third question, an interesting set of issues arose, but, at the time, they came under the broader question of the rigidity of the Confrontation Clause. The issues have changed a good deal with the Court's decision in Crawford v. Washington, 541 U.S. 36 (2004).

86. Glasser v. United States, 315 U.S. 60, 87 (1942), superseded by statute, FED. R. EvID. 104(a), as recognized in Bourjaily, 483 U.S. at 171. 
Glasser decision, ${ }^{87}$ were concerned that if the declaration itself could be used to prove the factual predicate for the exception, there would be a "bootstrapping operation" in play. ${ }^{88}$ Or, as the Court there explained: "[S] uch declarations are admissible over the objection of an alleged coconspirator, who was not present when they were made, only if there is proof aliunde that he is connected with the conspiracy. Otherwise hearsay would lift itself by its own bootstraps to the level of competent evidence." $" 89$

Without getting into the intricacies here of evidence law, one must realize that in Bourjaily the Court had to construe the recently enacted Federal Rules of Evidence to decide whether the earlier Glasser limitation had been withdrawn by Congress. In taking the government position, the six-Justice majority looked to the language of the Rules and thoroughly downplayed the concerns earlier expressed in Glasser:

[A] piece of evidence, unreliable in isolation, may become quite probative when corroborated by other evidence. A per se rule barring consideration of these hearsay statements during preliminary factfinding is not therefore required. Even if out-of-court declarations by co-conspirators are presumptively unreliable, trial courts must be permitted to evaluate these statements for their evidentiary worth as revealed by the particular circumstances of the case. Courts often act as factfinders, and there is no reason to believe that courts are any less able to properly recognize the probative value of evidence in this particular area.

\section{Id.}

88. Id. at 75 .

89. Id. at $74-75$ (citations omitted). The Court reaffirmed this position in United States v. Nixon, 418 U.S. 683, 701 (1974) ("Declarations by one defendant may also be admissible against other defendants upon a sufficient showing, by independent evidence, of a conspiracy among one or more other defendants and the declarant and if the declarations at issue were in furtherance of that conspiracy.").

90. Bourjaily, 483 U.S. at 180 . On the matter of the language of the new federal rules, the majority was also somewhat dismissive of the defense position:

Petitioner concedes that Rule 104, on its face, appears to allow the court to make the preliminary factual determinations relevant to Rule $801(\mathrm{~d})(2)(\mathrm{E})$ by considering any evidence it wishes, unhindered by considerations of admissibility. That would seem to many to be the end of the matter. Congress has decided that courts may consider hearsay in making these factual determinations. Out-of-court statements made by anyone, including putative co-conspirators, are often hearsay. Even if they are, they may be considered, Glasser and the bootstrapping rule notwithstanding. But petitioner nevertheless argues that the bootstrapping rule, as most Courts of Appeals have construed it, survived this apparently unequivocal change in the law unscathed and that Rule 104, as applied to the admission of co-conspirator's statements, does not mean what it says. We disagree.

Petitioner claims that Congress evidenced no intent to disturb the bootstrapping rule, 
This result did not have to be. After all, most federal circuit courts prior to Bourjaily had found that Glasser remained in force even after the adoption of the Federal Rules. To be sure, even today, many state courts looking to their own identical sections on co-conspirator declarations will not allow those declarations to be considered in deciding the factual predicate. ${ }^{91}$ More to the point, however, is the reason courts have

which was embedded in the previous approach, and we should not find that Congress altered the rule without affirmative evidence so indicating. It would be extraordinary to require legislative history to confirm the plain meaning of Rule 104. The Rule on its face allows the trial judge to consider any evidence whatsoever, bound only by the rules of privilege. We think that the Rule is sufficiently clear that to the extent that it is inconsistent with petitioner's interpretation of Glasser and Nixon, the Rule prevails.

Id. at $178-79$ (citation omitted).

91. The District of Columbia Court of Appeals, not bound by the Federal Rules, recently revisited the matter and agreed with the Bourjaily dissenters, explaining the need for the independent evidence requirement:

(1) it "ensures the reliability of coconspirator's statements admitted at trial by determining that sufficient corroborating evidence of a conspiracy exists," and (2) it "guards against the danger of 'bootstrapping,' i.e., using hearsay evidence to justify its own admission."

Jenkins v. United States, 80 A.3d 978, 990 (D.C. 2013) (internal citation omitted). The Jenkins court set out the decisions of the several state courts which have rejected the position of the Bourjaily majority. Id. at $992 \mathrm{n} .30$. While highly significant, Bourjaily ought not to be overstated. That is, the majority there expressly held open the question of whether the hearsay statement itself could be the entire basis for the factual predicate: "We need not decide in this case whether the courts below could have relied solely upon Lonardo's hearsay statements to determine that a conspiracy had been established by a preponderance of the evidence." Bourjaily, 483 U.S. at 181. In fact, almost all courts - both state and federal-looking to the matter do require other independent evidence of the conspiracy before the co-conspirator's declaration can be admitted. United States v. Gewin, 471 F.3d 197, 201 (D.C. Cir. 2006); Commonwealth v. Feliciano, 67 A.3d 19, 27 (Pa. Super. Ct. 2013); United States v. Brockenborrugh, 575 F.3d 726, $735-36$ (D.C. Cir. 2009). The court in State v. Hudson echoed the earlier statement of the United States Supreme Court:

The purpose of requiring independent evidence to establish a conspiracy is "to prevent the danger of hearsay evidence being lifted by its own bootstraps, i.e., relying on the hearsay statements to establish the conspiracy, and then using the conspiracy to permit the introduction of what would otherwise be hearsay testimony in evidence."

775 N.W.2d 429, 436 (Neb. 2009) (internal citation omitted).

One District Judge explained the rationale for his ruling:

Under the pre-Bourjaily standard, this extremely incriminating hearsay statement by a conspirator linking a fellow defendant to the conspiracy would be irrelevant in determining its own admissibility under Rule 801(d)(2)(E). Under the liberal interpretation of Bourjaily, this statement could be sufficient by itself to permit its admission to the jury. The court believes that this latter interpretation of Bourjaily would be the logical equivalent of the Queen of Hearts call for "sentence first-verdict afterwards." L. Carroll, Alice's Adventures in Wonderland (Oxford University Press 1983), at 165. Moreover, it would usurp the screening function of the court and encourage the manufacture of testimony in criminal conspiracy cases. The better view requires the government to present independent evidence which corroborates the hearsay's inference that a defendant was a coconspirator of the hearsay declarant.

United States v. Gambino, 728 F. Supp. 1150, 1155 (E.D. Pa. 1989).

Later Congressional action clearly established what the majority in Bourjaily avoided, a requirement 
required independent evidence with the co-conspirator hearsay exception: it is grounded in sound policy.

We typically do not allow hearsay statements in at trials for fear that without proper cross-examination of the original declarant we cannot feel confident that the underlying statement is one that should be trusted. ${ }^{92}$ Under Rule 803 of the Federal Rules of Evidence, a number of exceptions to this principle are laid out. See, for instance, these:

- Statements made for medical diagnosis or treatment.

- Records of a regularly conducted activity.

- $\quad$ Learned treatises.

- Excited utterances. ${ }^{93}$

The thread with these exceptions is that while the statements are hearsay, they may generally be viewed as reliable. After all, why would a scholar lie in a treatise? Who could imagine a patient not giving accurate information when discussing a medical condition with a doctor

under the Rule that the statement itself cannot be the only evidence to support the necessary findings: "The statement must be considered but does not by itself establish the declarant's authority under (C); the existence or scope of the relationship under (D); or the existence of the conspiracy or participation in it under (E)." FED. R. EvID. 801. As explained in the advisory committee's note to 1997 amendment:

[T] he amendment resolves an issue on which the Court had reserved decision. It provides that the contents of the declarant's statement do not alone suffice to establish a conspiracy in which the declarant and the defendant participated. The court must consider in addition the circumstances surrounding the statement, such as the identity of the speaker, the context in which the statement was made, or evidence corroborating the contents of the statement in making its determination as to each preliminary question. This amendment is in accordance with existing practice. Every court of appeals that has resolved this issue requires some evidence in addition to the contents of the statement.

FED. R. EvID. 801 advisory committee's note to 1997 amendment; see Wiest v. Lynch, 15 F. Supp. 3d 543, 563 n.14 (E.D. Pa. 2014).

92. Judge Posner, concurring in United States v. Boyce, remarked:

One reason that hearsay normally is inadmissible (though the bar to it is riddled with exceptions) is that it often is no better than rumor or gossip, and another, which is closely related, is that it can't be tested by cross-examination of its author.

742 F.3d 792, 800 (7th Cir. 2014) (Posner, J., concurring).

He went on to call for an overhaul of the whole system involving hearsay.

The "hearsay rule" is too complex, as well as being archaic. Trials would go better with a simpler rule, the core of which would be the proposition (essentially a simplification of Rule 807) that hearsay evidence should be admissible when it is reliable, when the jury can understand its strengths and limitations, and when it will materially enhance the likelihood of a correct outcome.

Id. at 802 .

93. See cases cited infra note 94 . 
or nurse $?^{94}$

With the co-conspirator hearsay exception, however, no one contends that the declaration is inherently reliable. To be sure, Justice Black almost seventy years ago expressed the view, shared by others, that " $[\mathrm{t}]$ here are many logical and practical reasons that could be advanced against a special evidentiary rule that permits out-of-court statements of one conspirator to be used against another." 95 It is not reliability or trustworthiness that is the basis for the exception. ${ }^{96}$ Rather, the entire grounding of the exception is a legal fiction that has been oft noted. Justice Blackmun, in his dissent in Bourjaily, discussed this point - a discussion that was not challenged by the majority. The coconspirator exception unquestionably is based on agency principles: "the underlying concept being that a conspiracy is a common undertaking where the conspirators are all agents of each other and where the acts and statements of one can be attributed to all." ${ }^{, 97}$

94. As explained in the advisory committee note, "Rule $803 \ldots$ is based upon the assumption that a hearsay statement falling within one of its exceptions possesses qualities which justify the conclusion that whether the declarant is available or unavailable is not a relevant factor in determining admissibility." FED R. EVID. 803 advisory committee's note to 1972 amendment. For an excellent discussion, see Jeffrey Bellin, The Case for eHearsay, 83 FORDHAM L. REV. 1317, 1330 (2014). For judicial affirmations of the reliability notion, see the following cases:

Medical Diagnosis: United States v. Chaco, 801 F. Supp. 2d 1200, 1211 (D.N.M. 2011) ("The Rule 803(4) exception to the hearsay rule is founded on a theory of reliability that emanates from the patient's own selfish motive-her understanding 'that the effectiveness of the treatment received will depend upon the accuracy of the information provided to the physician."') (internal citation omitted).

Business Records: Rambus, Inc. v. Infineon Techs. AG, 348 F. Supp. 2d 698, 702 (E.D. Va. 2004) ("The theory behind the business records exception embodied in Rule 803(6) is that " $\mathrm{r}$ ] eports and documents prepared in the ordinary course of business are generally presumed to be reliable and trustworthy.' Records of that sort are considered trustworthy because 'businesses depend on such records to conduct their own affairs; accordingly, the employees who generate them have a strong motive to be accurate and none to be deceitful' and secondly, because 'routine and habitual patterns of creation lend reliability to business records."') (internal citations omitted).

Learned Treatise: Costantino v. Herzog, 203 F.3d 164, 170-71 (2d Cir. 2000). ("The rationale for this exception is self-evident: so long as the authority of a treatise has been sufficiently established, the factfinder should have the benefit of expert learning on a subject, even though it is hearsay.").

95. Krulewitch v. United States, 336 U.S. 440, 443 (1949).

96. As explained in one thoughtful commentary, truly no one looks to reliability or trustworthiness as the reason to have the co-conspirator hearsay exception. David S. Davenport, The Confrontation Clause and the Co-Conspirator Exception in Criminal Prosecutions: A Functional Analysis, 85 HARV. L. REV. 1378, 1384-85 (1972) (“[T]he major development of the exception has been the result of a seemingly random appeal to various of the following rationales: (1) a characterization of conspiracy as a relationship of mutual agency, with the admissions of one conspirator thereby being treated as vicarious admissions by the others; (2) a characterization of many of the statements of conspirators as 'acts' of the conspiracy (elements, in themselves, of the crime); and (3) an allegation of special need for lax rules of evidence in prosecutions for such a traditionally secret and inchoate crime.") (internal citations omitted).

97. Bourjaily v. United States, 483 U.S. 171, 188 (1987) (Blackmun, J., dissenting). For a 
As stated rather succinctly by one state supreme court, "[T]he admissibility of [this exception] does not depend on trustworthiness." No, the rationale here is quite different, and this rationale can be seen as linked to the famous statement of Judge Learned Hand, repeated throughout the years: "[w]hen men enter into an agreement for an unlawful end, they become ad hoc agents for one another, and have made 'a partnership in crime.' What one does pursuant to their common purpose, all do, and as declarations may be such acts, they are competent against all.," 99

The problem with the opinion in Bourjaily is not necessarily the end result reached, ${ }^{100}$ but rather yet again an insensitivity to or unwillingness to acknowledge any defense claim of undue prejudice in a conspiracy prosecution. In many, perhaps most, cases, the prosecutor will be able to offer considerable non-hearsay evidence to support findings of a conspiracy to which the statement relates and a conclusion that the statement was made during the course of and in furtherance of that conspiracy. This may be true in most such cases - but not all. And, in a close case, that damning determination will be based not on a belief that the statement is nevertheless reliable, but rather on the agency fiction. Resolving such an important matter on a legal fiction seems dubious at best. As Justice Holmes wisely observed long ago, "When logic and ... policy ... conflict with a fiction due to historical tradition, the fiction must give way."

\section{E. Those Joint Trials Certainly Appear More Efficient}

[There is] the specific prejudice that results when defendants become weapons against each other, clawing into each other with antagonistic defenses. Like the wretches in Dante's hell, they may become entangled and ultimately fuse together in the eyes of the jury, so that neither defense is believed and all defendants are convicted.

\footnotetext{
good discussion of Justice Blackmun's dissent, see Byrd v. State, 187 S.W.3d 436, 440 (Tex. Crim. App. 2005).

98. State v. Tedesco, 513 A.2d 1164, 1167 (Vt. 1986) (internal citation omitted), overruled in part on other grounds in State v. Gallagher, 554 A.2d 221, 223 (Vt. 1988). The court in Tedesco explained that under the Vermont Rules of Evidence, statements by a co-conspirator are treated as admissions by a party-opponent. Id. This would also be true under the Federal Rules.

99. Van Riper v. United States, 13 F.2d 961, 967 (2d Cir. 1926) (internal citations omitted).

100. And, as noted above, Congress on its own thereafter amended the Rule. Supra note 91.

101. Blackstone v. Miller, 188 U.S. 189, 206 (1903), overruled in part by Farmers' Loan \& Trust Co. v. Minnesota, 280 U.S. 204 (1930).

102. United States v. Romanello, 726 F.2d 173, 174 (5th Cir. 1984).
} 
There was a time, not so very long ago, when courts recognized that antagonistic defenses offered in multiple defendant conspiracy trials created such a difficult dilemma for all that there was a hard rule, or at least a strong presumption, in favor of separating the defendants, severing such trials. ${ }^{103}$ After the United States Supreme Court's 8-1 decision in Zafiro $v$. United States, ${ }^{104}$ that position is long gone, replaced instead with the notion that "[m] utually antagonistic defenses are not prejudicial per se." 105

The decision in Zafiro matters a great deal and is, in my judgment, wrong as a matter of policy. The Justices were again highly insensitive to serious defense claims, here that problems can arise in multiple defendant criminal trials. Let me state, at the outset, that I am not suggesting that the presumption generally as to single trials for multiple defendants is somehow misguided or inappropriate. The rule has been around for many decades, ${ }^{106}$ and in the vast majority of cases little concern is raised as to such joinder of defendants. Zafiro, however, did not involve the usual sort of joinder. Here, at least arguably, the issue was one of antagonistic defenses. ${ }^{107}$ And, in such a situation, the strong presumption of joinder ought not to be the standard.

103. See Scott Hamilton Dewey, The Case of the Missing Holding: The Misreading of Zafiro v. United States, the Misreplication of Precedent, and the Misfiring of Judicial Process in Federal Jurisprudence on the Doctrine of Mutually Exclusive Defenses, 41 VAL. U. L. REV. 149, 152 (2006) (noting that the Supreme Court in Zafiro, infra, "contradicted existing practices in most circuits, which by then presumed a mandatory severance rule for irreconcilable defenses . ...").

104. 506 U.S. 534 (1993).

105. Id. at 537-38; see also Dewey supra note 104, at 152.

106. Statements abound in both federal and state court decisions that "defendants who are jointly indicted should be tried together." See Harris v. Commonwealth, Nos. 2011-CA-002336MR, 2012-CA-000024-MR, 2013 WL 4508002, at*3-4 (Ky. Ct. App. Aug. 23, 2013); United States v. Driver, 535 F.3d 424, 427-28 (6th Cir. 2008); United States v. Baker, 432 F.3d 1189, 1236 (11th Cir. 2005), abrogated on other grounds by Davis v. Washington, 547 U.S. 813, 821 (2006); People v. Mahaffey, 651 N.E.2d 174, 187 (Ill. 1995); United States v. Vega, 309 F. Supp. 2d 609, 614-15 (S.D.N.Y. 2004) ("There is a preference in the federal system for joint trials of defendants who are indicted together, because joint trials promote efficiency and avoid the problems of inconsistent verdicts.") (internal citations omitted); United States v. Druzenko, Nos. 12-404101/04-CR-C-BP, 13-4026-01/02-CR-C-BP, 2013 WL 5741088, at *1 (W.D. Mo. Oct. 23, 2013) (" $[R]$ arely, if ever will it be improper for co-conspirators to be tried together" (citing United States v. Patterson, 140 F.3d 767, 774 (8th Cir. 1998))); Diaz-Dumenigo v. United States, No. 11-2222(PG), 2014 WL 3870572, at*6 (D.P.R. Aug. 7, 2014) ("For severance to be granted, a defendant 'must demonstrate prejudice so pervasive that it would be likely to effect a miscarriage of justice."') (internal citations omitted). See generally People v. Mahboubian, 543 N.E.2d 34, 38 (N.Y. 1989) ("[P]ublic policy favors joinder, because it expedites the judicial process, reduces court congestion, and avoids the necessity of recalling witnesses.").

107. It turns out that the defendants in Zafiro, while claiming antagonistic defenses, did not actually show such irreconcilable differences, as analyzed by Justice Stevens in his concurrence. See infra notes 113-20 and accompanying text. 
There are many multiple defendant criminal trials and it would be impossible to have severance allowed in all such cases. Justice Scalia, almost 30 years ago, wrote that "[j] oint trials play a vital role in the criminal justice system, accounting for almost one-third of federal criminal trials in the past five years." 108 And, as he pointed out, quite a number of those trials can be extremely large. "Many joint trials-for example, those involving large conspiracies to import and distribute illegal drugs - involve a dozen or more codefendants." 109 To routinely grant severance in all joint defendant trials would be terribly disruptive with little benefit even for the charged defendants.

Still, what has happened since Zafiro is quite striking. Defendants rarely have severance motions granted, leading some courts to write that "it will be the rare case, if ever, where a district court should sever the trial of alleged coconspirators." "And, severance motion denials are not at all limited to the non-antagonistic defense cases. There are numerous cases, usually relying on Zafiro, where trial judges do not grant motions to sever even with an offering of antagonistic defenses. Many cases involve trial judges denying motions for severance and citing both the holding and language of Zafiro. As stated in one appeals decision:

[The defendant] is left with a prejudicial-joinder argument-that antagonistic defenses required severance. Zafiro v. United States, however, forecloses that argument. Zafiro expressly held that severance is not required when codefendants present mutually antagonistic defenses. Since Zafiro, we have consistently held that

108. Richardson v. Marsh, 481 U.S. 200, 208 (1987). He relied on a memorandum from the Administrative Office of the United States Courts to the Supreme Court Library. Extensive searching has not uncovered any more recent statistics on point, though few experienced criminal defense professionals would contend that the numbers have declined. The closest research on point was conducted about ten years ago on joint charges in the federal system. See Andrew D. Leipold \& Hossein A. Abbasi, The Impact of Joinder and Severance on Federal Criminal Cases: An Empirical Study, 59 VAND. L. REV. 349, 364-65 (2006) ("During the same five-year period, nearly two-thirds $(65 \%)$ of federal defendants were charged alone, while the remaining one-third were joined with others, either in the original indictment or via Rule 13.”).

109. Richardson, 481 U.S. at 209. Those numbers have seemingly not declined much in the years after the decision, as I explained a few years after the decision in Richardson. See Paul Marcus, Criminal Conspiracy Law: Time to Turn Back From an Ever Expanding, Ever More Troubling Area, 1 WM. \& MARY BILL RTS. J. 1 (1992). For a look at more recent such cases, see United States v. Munoz-Franco, 487 F.3d 25, 30 (1st Cir. 2007) (15-month trial, four defendants were found guilty of bank fraud, conspiracy, and misapplication of bank funds); Baker, 432 F.3d at 1198-1200 (15 indicted co-conspirators, a 17-count indictment, and a seven-week trial with almost 100 witnesses and considerable physical evidence); United States v. Tocco, 200 F.3d 401, 410-11 (6th Cir. 2000) (three-month trial with six defendants; defendant had been charged in a 25-count indictment along with 16 co-defendants on charges relating to the activities of "Cosa Nostra," but the trial court severed the trial of six defendants).

110. United States v. Frazier, 280 F.3d 835, 844 (8th Cir. 2002). 
blame-shifting among codefendants, without more, does not mandate severance.

The result in Zafiro was neither inevitable nor necessarily predictable. As the case developed, two things became clear. First, the defendants in the case did not really raise antagonistic defenses. True antagonistic defenses in multiple defendant trials are not terribly common. As pointed out by Justice O'Connor in her majority opinion ${ }^{112}$ and Justice Stevens in his concurring opinion, a true defense which is "mutually antagonistic" to another defense means that "acceptance of one defense... necessarily preclude[s] acceptance of the other and acquittal of the codefendant."113 The defenses must be "mutually exclusive."114 The defendants must be on an evidentiary "collision course." 115 It is not enough that there be conflicting arguments by the defense lawyers, ${ }^{116}$ or that there is "fingerpointing" by each side. ${ }^{117}$ In Zafiro, neither defendant involved testified, and each defense claim was simply that the government had not shown his guilt beyond a reasonable doubt. The essence of their position was that the individual defendant did not know the contents of a box (which contained a whole lot of cocaine). ${ }^{118}$ As Justice Stevens wrote, the trial judge was correct in concluding that the defenses presented in Zafiro were not mutually antagonistic.

When two people are apprehended in possession of a container filled with narcotics, it is probable that they both know what is inside.

111. United States v. Plato, 629 F.3d 646, 650 (7th Cir. 2010) (citations omitted). For other examples of such rulings, all relying on Zafiro, see Jenkins v. United States, 113 A.3d 535, 542 (D.C. 2015) ("irreconcilable defenses do not require severance if "the conflict in defenses alone would not sway the jury"' (quoting Tillman v. United States, 519 A.2d 116, 171 (D.C. 1986))); State v. Foster, 839 N.W.2d 783, 800 (Neb. 2013) (“'finger pointing' alone does not create mutually exclusive defenses sufficient to require separate trials"); Flores v. Long, No. EDCV 12-02031 CJC (AN), 2013 WL 5539554, at *8 (C.D. Cal. Oct. 4, 2013) (“[joint trial] expedites the administration of justice, reduces the congestion of trial dockets, conserves judicial time, lessens the burden upon citizens who must sacrifice both time and money to serve upon juries, and avoids the necessity of recalling witnesses who would otherwise be called upon to testify only once" (quoting Parker v. United States, 404 F.2d 1193, 1196 (9th Cir. 1968))).

112. Zafiro v. United States, 506 U.S. 534, 537 (1993).

113. Id. at 542 (Stevens, J., concurring).

114. See State v. Kinkade, 680 P.2d 801, 803 (Ariz. 1984); Zafiro, 506 U.S. at 545 n.1 (Stevens, J., concurring).

115. Hill v. State, 481 So. 2d 419, 424 (Ala. Crim. App. 1985).

116. See United States v. Davis, 177 F.3d 552, 558 (6th Cir. 1999).

117. Burns v. State, 638 S.E.2d 299, 300-01 (Ga. 2006).

118. Zafiro, 506 U.S. at 536. The defendants were charged with various drug offenses, including conspiracy, linked to the illegal contents of the box found in their possession. Id. at 53536. 
The inference of knowledge is heightened when, as in this case, both people flee when confronted by police officers, or both people occupy the premises in which the container is found. At the same time, however, it remains entirely possible that one person did not have such knowledge. That, of course, is the argument made by each of the defendants in this case: that he or she did not know what was in the crucial box or suitcase.

Most important here, it is also possible that both persons lacked knowledge of the contents of the relevant container. Moreover, that hypothesis is compatible with individual defenses of lack of knowledge. There is no logical inconsistency between a version of events in which one person is ignorant, and a version in which the other is ignorant; unlikely as it may seem, it is at least theoretically possible that both versions are true, in that both persons are ignorant. In other words, dual ignorance defenses do not necessarily translate into "mutually antagonistic" defenses, as that term is used in reviewing severance motions, because acceptance of one defense does not necessarily preclude acceptance of the other and acquittal of the codefendant. 119

The defendants could not satisfy the collision course requirement for antagonistic defenses, nor could either of them actually "articulate any specific instances of prejudice." 120 In short, this was the perfect case for the Court-acknowledging the inherent difficulties with multiple defendant conspiracy trials - to recognize the general preference for joint trials and, in Justice Stevens' words, "save for another day evaluation of the prejudice that may arise when the evidence or testimony offered by one defendant is truly irreconcilable with the innocence of a codefendant." ${ }^{\prime 21}$ The majority could just have disposed of the case using that approach. True, the defendants had requested a bright line rule "mandating severance whenever codefendants have conflicting defenses." 122 The Court could easily have rejected such a rigid rule, and have deferred consideration of that requirement. Instead, the majority strongly reaffirmed the preference notation, bringing within it cases involving antagonistic defenses actually stated.

The decision of the Court is broad, and it is of genuine significance.

119. Id. at 541-42 (Stevens, J., concurring) (citations omitted). The situation here was not exactly the extreme case contemplated by courts which had made special allowances for antagonistic defense scenarios, as in State v. White: "The classic example of intrinsically antagonistic defenses is where both defendants blame each other for the crime while attempting to defend against the State's case." State v. White, 67 P.3d 138, 147 (Kan. 2003) (quoting State v. Pham, 675 P.2d 848, 855 (Kan. 1984)).

120. Zafiro, 506 U.S. at 539 .

121. Id. at 543 (Stevens, J., concurring).

122. Id. at 538 . 
As noted above, prior to Zafiro, many courts had - at minimum - been favorably inclined to grant severance motions if true antagonistic defenses were presented. The Seventh Circuit opinion in Zafiro made this clear: "[A] vast number of cases say that a defendant is entitled to a severance when the 'defendants present mutually antagonistic defenses' in the sense that 'the acceptance of one party's defense precludes the acquittal of the other defendant ....",123 This is true no longer. Instead, today the norm is to hold that "[s]everance . . . is not mandated whenever co-defendants have conflicting defenses." 124

How did this state of affairs come about? The reason is rather plain to see: the Court in Zafiro was, here too, dismissive of the defense concerns. To be sure, not only did the Justices not find a mandatory severance requirement for cases involving antagonistic defenses generally, severance may not be needed even if prejudice can be shown. ${ }^{125}$ Instead, relief is left to the discretion of the trial judge, likely to be in the form of jury instructions. ${ }^{126}$ The decision was certain on this point: "[m]oreover, even if there were some risk of prejudice, here it is of the type that can be cured with proper instructions, and 'juries are presumed to follow their instructions." "127 Here is the Court's description of the instructions the jury received in Zafiro:

The District Court properly instructed the jury that the Government had "the burden of proving beyond a reasonable doubt" that each defendant committed the crimes with which he or she was charged. The court then instructed the jury that it must "give separate consideration to each individual defendant and to each separate charge

123. United States v. Zafiro, 945 F.2d 881, 885 (7th Cir. 1991).

124. State v. Daniels, 636 N.E.2d 336, 344 (Ohio Ct. App. 1993). See generally Collins v. Runnels, 603 F.3d 1127, 1131 (9th Cir. 2010) ("The [Zafiro] Court declined adopting such a brightline rule, holding that mutually antagonistic defenses are not prejudicial per se."); People v. Hardy, 825 P.2d 781, 828 (Cal. 1992) ("If the fact of conflicting or antagonistic defenses alone required separate trials, it would negate the legislative preference for joint trials and separate trials "would appear to be mandatory in almost every case."”) (quoting People v. Turner, 37 Cal. 3d 302, 313 (1984)).

125. Zafiro, 506 U.S. at 539.

126. Id.

127. Id. at 540 (quoting Richardson v. Marsh, 481 U.S. 200, 211 (1987). Whether jurors are indeed able to follow such a charge in a case in which defendants are fighting each other must be open to some question. Indeed, even Justice Scalia in Richardson wondered out loud about this in that setting:

The rule that juries are presumed to follow their instructions is a pragmatic one, rooted less in the absolute certitude that the presumption is true than in the belief that it represents a reasonable practical accommodation of the interests of the state and the defendant in the criminal justice process.

Richardson, 481 U.S. at 211. 
against him. Each defendant is entitled to have his or her case determined from his or her own conduct and from the evidence [that] may be applicable to him or to her." In addition, the District Court admonished the jury that opening and closing arguments are not evidence and that it should draw no inferences from a defendant's exercise of the right to silence. ${ }^{128}$

While the direction was seemingly "boiler plate" in nature and not at all tailored to the facts involved, Justice O'Connor found that " $\mathrm{t}] \mathrm{h}$ hese instructions sufficed to cure any possibility of prejudice." 129

If, then, such standard instructions will normally be sufficient to eliminate prejudice even with antagonistic defenses, what will it take for a judge to feel obliged to order severance? The answer: quite a lot. As a practical matter, one sees few severance orders after Zafiro based on claims of antagonistic defenses. ${ }^{130}$ The reason for this is that the Court in Zafiro set the standard quite high in terms of what must be shown by the defendant to warrant a severance. The order should only be granted if there is a "serious risk that a joint trial would compromise a specific trial right of one of the defendants, or prevent the jury from making a reliable judgment about guilt or innocence." 131

Several examples of somewhat extreme situations were offered by

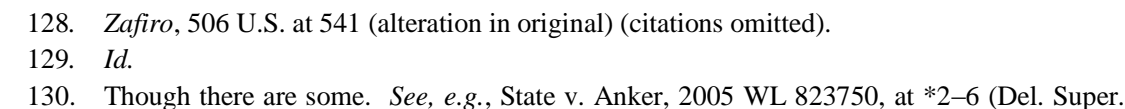
Ct. Apr. 4, 2005); United States v. Mayfield, 189 F.3d 895, 900 (9th Cir. 1999); State v. Tate, 657 So. 2d 567, 568-69 (La. Ct. App. 1995); State v. Robinson, Nos. IK93-10-0475-0477, IK93-100478-0480, 1994 WL 684483, at*1-2 (Del. Super. Ct. Oct. 7, 1994). As written in People v. Nixon, severance was required because "there [was] a significant danger, as both defenses [were] portrayed to the trial court [in the pretrial motion and the motion for a mistrial], that the conflict alone would lead the jury to infer defendant's guilt." 908 N.Y.S.2d 293, 294 (N.Y. App. Div. 2010) (quoting People v. Mahboubian, 74 N.Y.2d 174, 184 (N.Y. 1989). Prior to Zafiro, such decisions were somewhat routine. For a particularly strong ruling, see People v. Cardwell:

Special factors unique to this case compel us to conclude that there should have been a severance. These factors include the conduct of the trial itself. While no one factor is dispositive in such matters, we note that in this case McCoy's attorney took an aggressive adversarial stance against both Goss and Cardwell, in effect becoming a second prosecutor. Goss' attorney then responded by attempting to impeach McCoy's story with evidence of a recantation, which elicited an assertion from McCoy that the recantation had been induced by Cardwell's threats - damaging evidence elicited not by the People, but by a codefendant. ... [T]his entire situation "created the sort of compelling prejudice that could have been avoided by the grant of the requested severance."

580 N.E.2d 753, 754 (N.Y. 1991) (quoting People v. Mahboubian, 74 N.Y.2d 174, 186 (N.Y. 1989)).

131. Zafiro, 506 U.S. at 539. After extensive research and various search approaches, my research assistant and I were unable to determine the exact number of decisions which rely on Zafiro to reject severance requests. Using Westlaw's functions we found that well over 2000 state and federal decisions cite Zafiro while discussing trial severance. While lacking precise numbers, it is easy for me to conclude that almost all of them neither grant motions for severance nor reverse denials of such motions. 
the majority. ${ }^{132}$ Still, those situations will not be common and will not begin to address Justice Stevens' more general concern:

[that joinder] may invite a jury confronted with two defendants, at least one of whom is almost certainly guilty, to convict the defendant who appears the more guilty of the two regardless of whether the prosecutor has proven guilt beyond a reasonable doubt as to that particular defendant. Though the Court is surely correct that this second risk may be minimized by careful instructions insisting on separate consideration of the evidence as to each codefendant, the danger will remain relevant to the prejudice inquiry in some cases. ${ }^{133}$

Indeed, the lower federal courts [and many state courts as well] have looked to Zafiro and concluded that it does indeed impose "a limit on [trial judges' traditional] discretion ['to consider severance whenever mutually antagonistic defenses are presented']." ${ }^{134}$ In fact, quite a number of courts, relying on Zafiro, have gone well beyond the language of the decision, in requiring for a successful motion to sever a showing of substantial harm. "“[P]otential for prejudice' is not enough, and instead,

132. Id. at 539, stating:

We believe that, when defendants properly have been joined under Rule 8(b), a district court should grant a severance under Rule 14 only if there is a serious risk that a joint trial would compromise a specific trial right of one of the defendants, or prevent the jury from making a reliable judgment about guilt or innocence. Such a risk might occur when evidence that the jury should not consider against a defendant and that would not be admissible if a defendant were tried alone is admitted against a codefendant. For example, evidence of a codefendant's wrongdoing in some circumstances erroneously could lead a jury to conclude that a defendant was guilty. When many defendants are tried together in a complex case and they have markedly different degrees of culpability, this risk of prejudice is heightened. Evidence that is probative of a defendant's guilt but technically admissible only against a codefendant also might present a risk of prejudice. Conversely, a defendant might suffer prejudice if essential exculpatory evidence that would be available to a defendant tried alone were unavailable in a joint trial.

(citations omitted).

133. Id. at 544 (Stevens, J., concurring) (citation omitted). He stated the matter rather forcefully: A joint trial involving "joinder may introduce what is in effect a second prosecutor into a case, by turning each codefendant into the other's most forceful adversary." Id. "[M]utually exclusive defenses [may] transform a trial into "more of a contest between the defendants than between the people and the defendants." Id . at 543. The court in United States v. Green nicely stated the problem:

The issue is whether a jury will be able to hear the opposing position - the defense theory - and reliably consider all positions. There is a considerable risk that each defendant, ably throwing pot-shots at the other, would make the government's case for it. Specifically, in the din, a juror could well say: "I cannot figure out who did the shooting, given the defendants' mutual accusations, but it doesn't matter. They were involved somehow and that is enough." That conclusion would redound to the government's benefit.

324 F. Supp. 2d 311, 325 (D. Mass. 2004).

134. Zafiro, 506 U.S. at 545 (Stevens, J., concurring). 
the prejudice must be "compelling.",135 One federal appeals decision certainly reinforced the tone of the Zafiro opinion, if not the exact language:

[T] he rule about a joint trial in conspiracy cases is not quite ironclad. The exceptional circumstances justifying a deviation from the rule, however, are few and far between. A defendant seeking a severance must carry the "heavy burden of demonstrating [that] compelling prejudice" would result from a joint trial. ${ }^{136}$

In short, one commentator was quite correct when he wrote, more than 15 years ago: "As a practical matter, Zafiro has made it exceedingly difficult for a defendant to persuade a trial judge to grant a severance motion, especially in conspiracy prosecutions." 137

What is especially troubling about the Court's decision, and the many cases following it, is that with all the severance motions, trial judges are construing statutory provisions, which call for such severance in the appropriate case. In the federal system, those provisions are Rules 8(b) and 14 of the Federal Rules of Criminal Procedure. ${ }^{138}$ The former establishes the basis for joinder, the latter for severance. Rule 8(b) provides for relatively simple joinder of co-conspirators: "The indictment or information may charge 2 or more defendants if they are alleged to have participated in the same act or transaction, or in the same series of acts or transactions, constituting an offense or offenses." 139 The key here is Rule 14: "If the joinder of ... defendants ... for trial appears to prejudice a defendant or the government, the court may order separate trials of counts, sever the defendants' trials, or provide any other relief that justice requires." ${ }^{\prime 40}$ Justice O'Connor in Zafiro focused attention on the merits of Rule 8(b) in allowing for joinder and creating judicial efficiency and basic fairness. Joint trials "are designed "to promote

135. United States v. Fagan, 518 F. App'x 749, 752 (11th Cir. 2013) (citing United States v. Lopez, 649 F.3d 1222, 1234 (11th Cir. 2011)). See generally United States v. Sinha, No. 1:14cr9HSO-JMR, 2014 WL 1794862, at *1-2 (S.D. Miss. May 6, 2014); United States v. Williams, No. 2:14-cr-48-FtM-29DNF, 2014 WL 6469410, at *1-2 (M.D. Fla. Nov. 17, 2014); United States v. Grace, No. 4:09-CR-19-DPJ-LRA, 2010 WL 419381, at*1-3 (S.D. Miss. Jan. 29, 2010); United States v. Aiken, 76 F. Supp. 2d 1346, 1352 (S.D. Fla. 1999).

136. United States v. Lopez, 649 F.3d 1222, 1234 (11th Cir. 2011) (citations omitted).

137. Edward J. Imwinkelried, Prejudice to the Nth Degree: The Introduction of Uncharged Misconduct Admissible Only Against a Co-defendant at a Megatrial, 53 OKLA. L. ReV. 35, 36 (2000).

138. Most states have similar provisions. See, e.g., I.C.R. 8, 14; OHIO CRIM. R. 8, 14; UTAH CODE ANN. § 77-8a-1 (LexisNexis 2015).

139. FED. R. CRIM. P. 8(b).

140. FED. R. CRIM. P. 14(a). 
economy and efficiency and to avoid a multiplicity of trials." ${ }^{\prime 141}$ What she did very little of, however, was discuss how a defendant can be deeply hurt when -in Justice Stevens' words - "the evidence or testimony offered by one defendant is truly irreconcilable with the innocence of a codefendant." "142 And, this can happen, even when one is not able to show before trial any specific forms of compelling prejudice. Sadly, one does not see in the Zafiro majority opinion the type of thoughtful concern expressed in the pre-trial proceedings involving one of the truly horrific criminal acts of the previous century, the Oklahoma City bombing case. There the trial judge granted a motion to sever. $\mathrm{He}$ explained why:

Preference for a joint trial of persons charged with conspiracy and with aiding and abetting crimes assumes efficiencies resulting in conservation of resources, reduction in inconveniences to witnesses and public authorities, avoidance of delays and mitigation of adverse effects on witnesses and victims. Such assumptions must be analyzed for their validity in any particular case and their value may be outweighed by the compelling interest in the fairness and finality of the verdict.

There are efficiencies and advantages in single focused trials. The time needed for jury selection is significantly reduced: the number of defense peremptory challenges is halved and only one defense counsel conducts voir dire questioning. It is easier to apply the rules of evidence when there is a trial of one defendant, particularly with regard to the admissibility of statements offered under Rule 801(d)(2); character evidence under Rule 404(a)(1) and proof of motive, opportunity, intent, preparation, plan, knowledge and identity under Rule 404(b). Given these considerations, it is far from certain that the time required for two separate trials would, in total, be substantially greater than the time required for a joint trial.

\section{CONCLUSION}

There was a time, not so terribly long ago, when Justices of the United States Supreme Court were quite concerned with the elasticity of the conspiracy charge and the manner in which that charge was prosecuted. This attitude was reflected in numerous opinions mandating caution and restraint in prosecuting criminal conspiracies. That view seemingly has vanished from the Court. In both determining which cases

141. Zafiro v. United States, 506 U.S. 534, 540 (1993) (quoting Bruton v. United States, 391 U.S. 123, 131 n.6 (1968)).

142. Id. at 543 .

143. United States v. McVeigh, 169 F.R.D. 362, 370 (D. Colo. 1996). 
to review and in resolving those matters, the Justices instead have repeatedly emphasized that conspiracy - in the words of the drafters of the Model Penal Code - can [along with attempt and solicitation]create "infinite degrees of danger." 144 In the decisions discussed here, we have seen strong reaffirmations of prosecutorial positions and general dismissals of defense objections. This attitude is most unfortunate. It is true that conspiracies may, without question, need to be sanctioned. It is also true, however, that an overuse of the conspiracy doctrine along with a tipping of the procedural scales well beyond what had been seen before can create terribly difficult and unfair trial situations. It is time for the Supreme Court to take a more balanced and moderate approach to criminal conspiracy.

144. Herbert Wechsler et al., The Treatment of Inchoate Crimes in the Model Penal Code of the American Law Institute: Attempt, Solicitation, and Conspiracy, 61 Colum. L. Rev. 957, 1029 (1961). 